\title{
Population Biology of the Metazoan Parasites Infecting Fishes from Lakes Uba and Ruwe, Lower Rufiji Floodplain, Tanzania
}

\author{
Chacha J. Mwita ${ }^{*}$, Hieromin Lamtane ${ }^{2}$ \\ ${ }^{1}$ Department of Fisheries Science and Aquaculture, University of Dar-Es-Salaam, Dar-Es-Salaam, Tanzania \\ ${ }^{2}$ Department of Animal Science, Sokoine University of Agriculture, Morogoro, Tanzania \\ Email: ${ }^{*}$ mwitachacha@udsm.ac.tz
}

Received 17 April 2014; revised 17 May 2014; accepted 24 May 2014

Copyright (C) 2014 by authors and Scientific Research Publishing Inc.

This work is licensed under the Creative Commons Attribution International License (CC BY). http://creativecommons.org/licenses/by/4.0/

(c) (i) Open Access

\section{Abstract}

Out of the 48 fishes examined, 40 (83.3\%) were infected by 759 parasites, which comprise of trematodes, monogeneans, crustaceans and acanthocephalans. Acanthocephalans and strigeid trematodes were the majority, $23(47.9 \%)$ of all the parasites, while crustaceans, Ergasilus was the minority (20.8\%). Fish with length size greater than $160 \mathrm{~mm}$ were infected (prevalence 100\%). Strigeids showed the highest prevalence $(83.3 \%)$ and mean intensity $(24.7)$ in fish of total length 160 - $189 \mathrm{~mm}$ while those greater than $219 \mathrm{~mm}$ had the least prevalence $(20 \%)$ and mean intensity (2). Acanthocephalan showed the highest prevalence $(87.5 \%)$ and mean intensity (15.7) in fish of total length $190-219 \mathrm{~mm}$ and least prevalence (30.4\%) and mean intensity (5.6) in those with $130-159 \mathrm{~mm}$ in total length. Generally male fish had higher prevalence (88.5\%) and mean intensity (21.6) than female fish. However, statistically these were not significant $(P>0.05)$. A total of 9 parasite taxa were recovered; 5 from Oreochromis urolepis, 4 from Citharinus congicus, 2 from Clarias gariepinus and Synodontis maculipinna. Three groups of parasites were common in Oreochromis urolepis, these include Dactylogyrus, Acanthocephala, and strigid. Ergersilus lamelifer was common in Citharinus congicus and Clarias gariepinus. Nematodes, Procamalanus laevionchus and Oxyuridae were common in Synodontis maculipinna and Citharinus congicus respectively.

\section{Keywords}

Prevalence, Intensity, Parasites, Oreochromis urolepis, Rufiji, Tanzania

\footnotetext{
${ }^{*}$ Corresponding author.
}

How to cite this paper: Mwita, C.J. and Lamtane, H. (2014) Population Biology of the Metazoan Parasites Infecting Fishes from Lakes Uba and Ruwe, Lower Rufiji Floodplain, Tanzania. Natural Science, 6, 700-708. 


\section{Introduction}

Fish in wild and aquaculture farms face a wide range of enemies including competitors, predators and parasites. Parasites may induce a shift in fish species densities, size composition and affect commercially interesting stocks. This mainly depends on the vulnerability of species, habitats and seasonal factors [1]. Because of their complex life cycles, parasites are indicative of many aspects of their hosts' biology, such as host diet, migration, recruitment, population distinctness and even phylogeny [1]. Parasites are also good indicators of environmental contaminants and stress [2].

Fish parasites have had a great impact on the aquaculture industry causing losses to fish farmers [3]. Although the aquaculture industry is still young in many parts of Africa, the parasites of freshwater fish have already received considerable attention [4]-[6]. Unfortunately, fish parasites from the Rufiji floodplain lakes are yet to be studied.

In addition, most of the studies on fish parasites in Africa are restricted to Clariid fishes, specifically the parasites of Clarias gariepinus which, are covered extensively, with parasites of other fish species receiving little or no attention. The objectives of the present study therefore, were to determine the composition, prevalence and intensity of parasites infecting fishes commonly found in Lakes Uba and Ruwe in the lower Rufiji floodplains, south of Tanzania.

\section{Materials and Methods}

\subsection{Study Area}

Lakes Uba and Ruwe are situated north of River Rufiji and are among the 13 lakes found along the lower Rufiji floodplain. The two lakes lie in a narrow valley cut into the escarpment of the river terrace. These water bodies are elongated, bordered by steep, heavily wooded lateral slopes and with the trees extending down to the water edge. Small temporary streams or rivers drain into the upper end of Lake Ruwe and both lakes are connected with the river during the flooding season from March to May when water level rises. Lake Ruwe is $9 \mathrm{~km}$ from the river, $12.44 \mathrm{~km}^{2}$ in area with a mean depth of $2.5 \mathrm{~m}$. Lake Uba is smaller, $10 \mathrm{~km}$ from the river, $4.49 \mathrm{~km}{ }^{2}$ and has a mean depth of $2.0 \mathrm{~m}$ and a distance between the two lakes is $9 \mathrm{~km}$ (Figure 1).

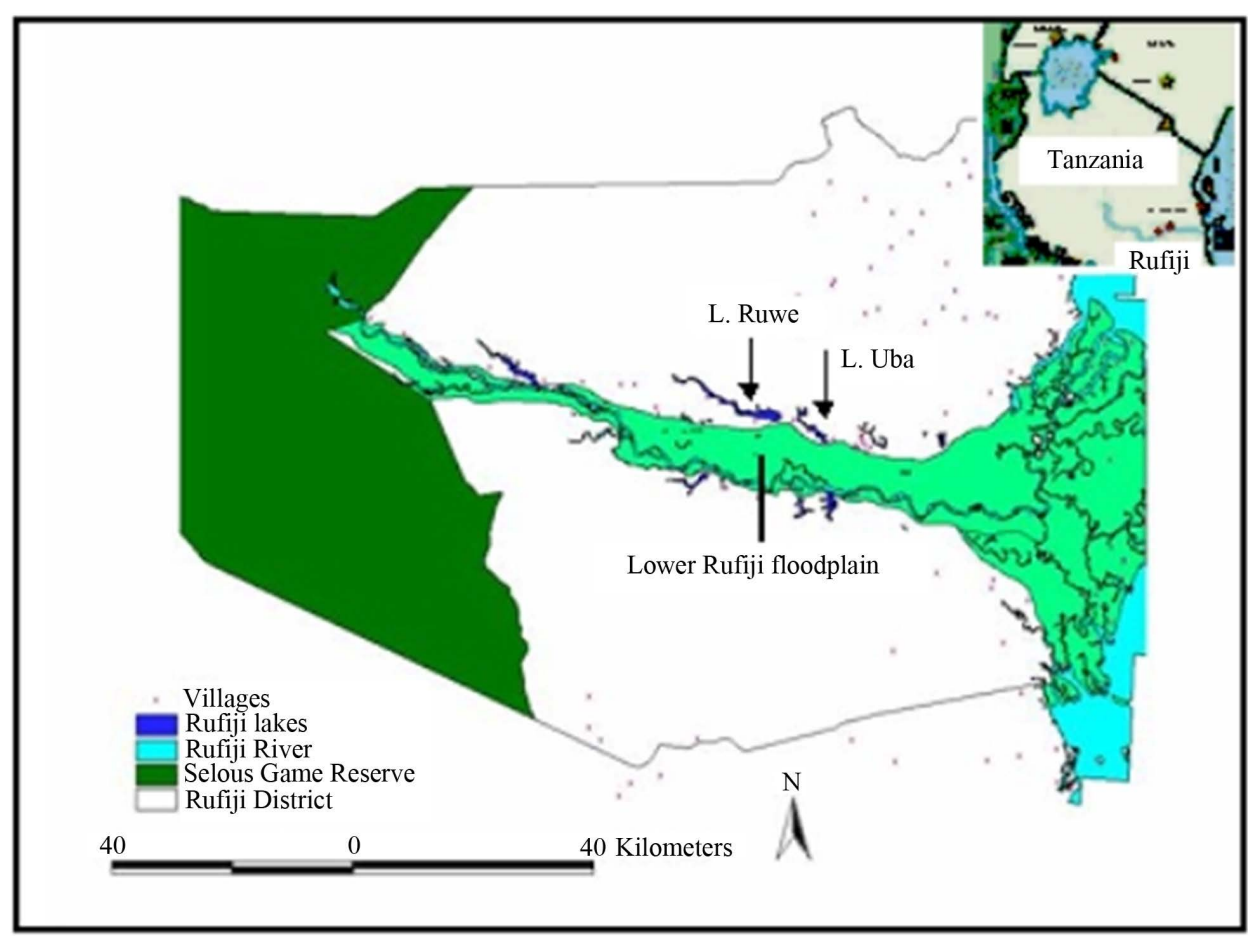

Figure 1. Map shows the location of the study area (Lakes Ruwe and Uba) along the lower Rufiji floodplain. 


\subsection{Fish and Parasites Sampling}

A total of 48 fishes were caught by the help of fishermen and examined for parasites. Fish were transported dead in cool box to the laboratory where they were frozen before examination. Length and body weight were measured before examination. Metazoan parasites were then isolated from eyes, brain, gills, stomach and intestine using standard methods [7]. Parasites were magnified $40 \times-100 \times$ by the help of a compound microscope and identified to different levels using available keys [8] [9]. Because of the smaller sample size data from the two lakes were pooled for further analysis.

\subsection{Data Analysis}

Parasite data are presented as prevalence (\% infected) and intensity of infection (number of parasite per infected fish) expressed as a mean \pm SE, followed by range as recommended by [10]. Parasite were designated common when prevalence exceeded $25 \%$ in a collection, uncommon when prevalence ranged from $5 \%-24 \%$ and rare for prevalence less than 5\% [11]. As parasite counts were not normally distributed, non-parametric analysis was used as per SPSS programme.

\section{Results}

\subsection{General Consideration}

Out of the 48 fishes examined, 40 (83.3\%) were infected by 759 parasites, which comprised of trematodes, monogeneans, crustaceans and acanthocephalans. Acanthocephalans and strigeid trematodes were the majority, 23 (47.9\%), while crustaceans, Ergasilus were the minority (20.8\%). The parasites were found in different body parts and classified as shown in Table 1.

\subsection{Parasites Prevalence and Mean Intensity in Relation to the Size of $O$. urolepis}

All fish with length size greater than $160 \mathrm{~mm}$ were infected (prevalence 100\%). Strigeids showed the highest prevalence (83.3\%) and mean intensity (24.7) in fish of total length 160 - $189 \mathrm{~mm}$ while those greater than 219 $\mathrm{mm}$ had the least prevalence (20\%) and mean intensity (2) (Figure 2(a) and Figure 2(b)). Acanthocephalan showed the highest prevalence (87.5\%) and mean intensity (15.7) in fish of total length $190-219 \mathrm{~mm}$ and least prevalence (30.4\%) and mean intensity (5.6) in those with 130 - $159 \mathrm{~mm}$ in total length (Figure 3(a) and Figure $3(b))$.

\subsection{Parasites Prevalence and Mean Intensity in Relation to the Sex 0 , urolepis}

Generally male fish had higher prevalence (88.5\%) and mean intensity (21.6) than female fish (Figure 4(a) and Figure 4(b)). However, statistically these were not significant $(\mathrm{P}>0.05)$. The prevalence and mean intensity of strigeids infection in female fish were higher than in the male (46.2\%) and (26.5\%) respectively (Figure 5(a) and Figure 5(b)), as opposed to that of the acanthocephalan which, were higher in male fish than in the females (45.5\%) and (8.3\%) respectively (Figure 6(a) and Figure 6(b)).

Table 1. Prevalence $(\mathrm{P})$, intensity (mean $\pm \mathrm{SE}$ ) and range of parasites of $O$. urolepis.

\begin{tabular}{ccccc}
\hline Parasite & Location & P (\%) & Intensity & Range \\
Trematodes & & & & \\
Strigids & Eye & 47.92 & $20.83 \pm 7.63$ & $1-167$ \\
Crustaecea & & & & $1-10$ \\
Ergasilus sp. & Gills & 20.83 & $2.50 \pm 0.87$ & $1 \pm 0.0$ \\
Lamproglena & Gills & 3.2 & & $1-8$ \\
Monogenia & & & $1.93 \pm 0.49$ & $1-40$ \\
Dactylogyrus sp. & Gills & 29.17 & $9.91 \pm 4.68$ & \\
Acanthocephala & Intestine & 47.92 & & \\
\hline
\end{tabular}



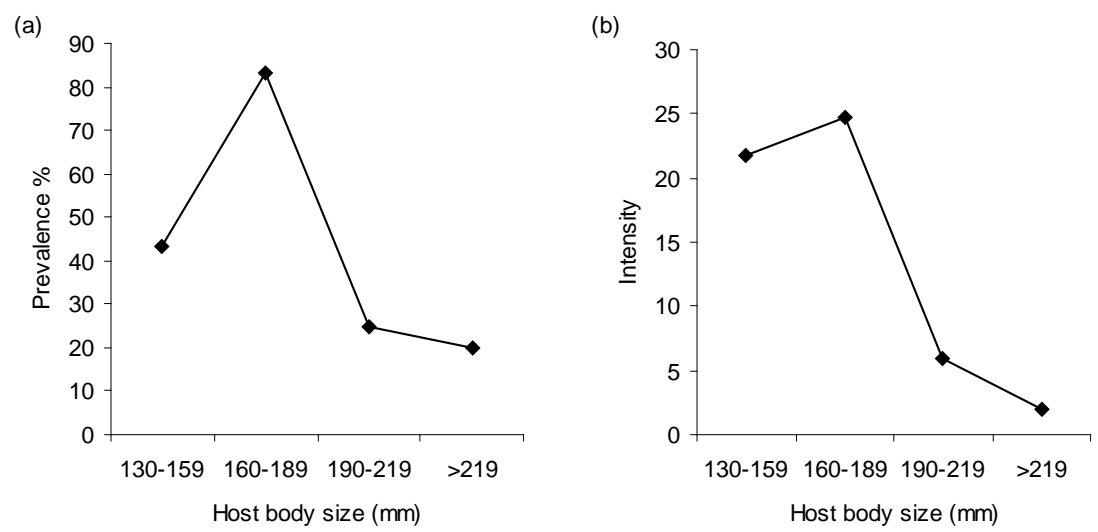

Figure 2. (a) Prevalence and (b) intensity of strigeid from O. urolepis.
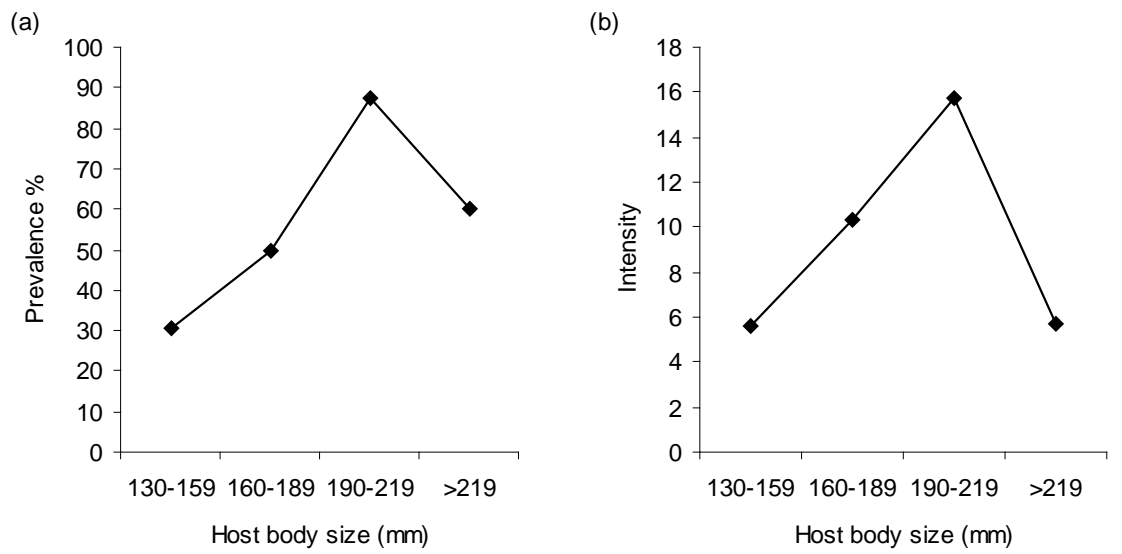

Figure 3. (a) Prevalence and (b) mean intensity of acanthocephalan from O. urolepis.
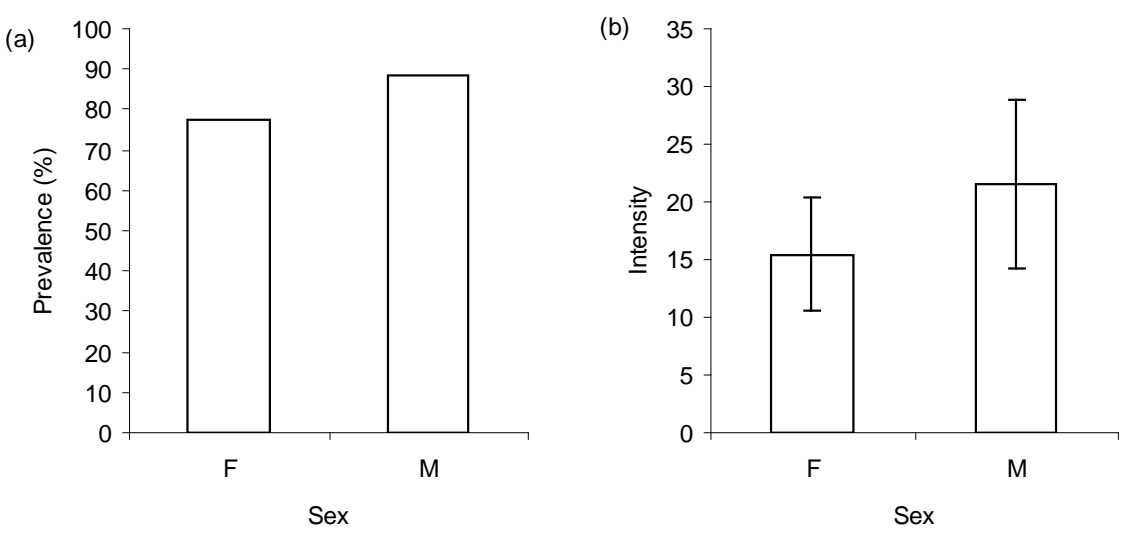

Figure 4. (a) Prevalence and (b) intensity of parasites of males and females of O. urolepis.

\subsection{Parasites Community Structure of the Four Fish Species Common in the Two Lakes}

Prevalence and intensity for all parasite taxa from each host species are provided in Table 2. A total of 9 parasite taxa were recovered; 5 from Oreochromis urolepis, 4 from Citharinus congicus, 2 from Clarias gariepinus and Synodontis maculipinna. Three groups of parasites were common in Oreochromis urolepis, these include Dactylogyrus, Acanthocephala, and strigid. Ergersilus lamelifer was common in Citharinus congicus and Clarias gariepinus. Nematodes, Procamalanus laevionchus and Oxyuridae were common in Synodontis maculipinna and Citharinus congicus respectively (Table 2). 
(a)

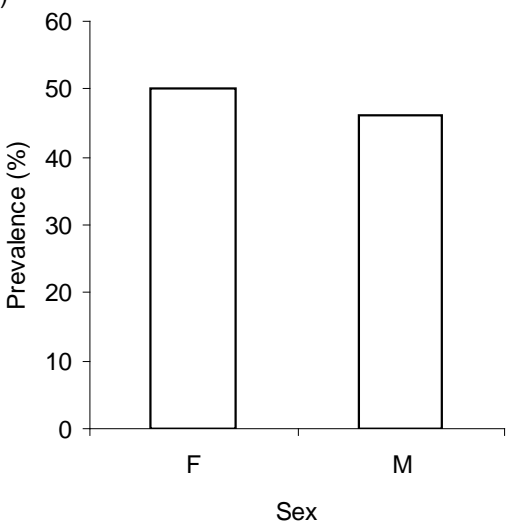

(b)

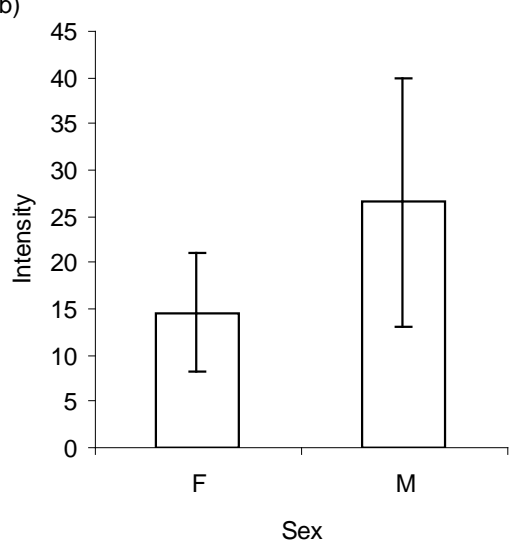

Figure 5. (a) Prevalence and (b) intensity of strigeid of males and females of $O$. urolepis.

(a)

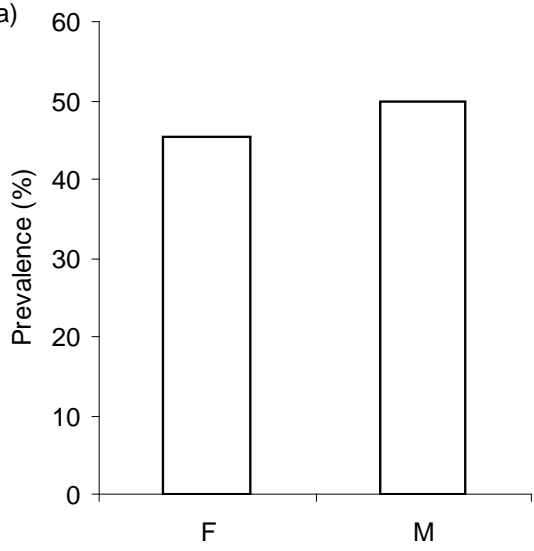

Sex (b)

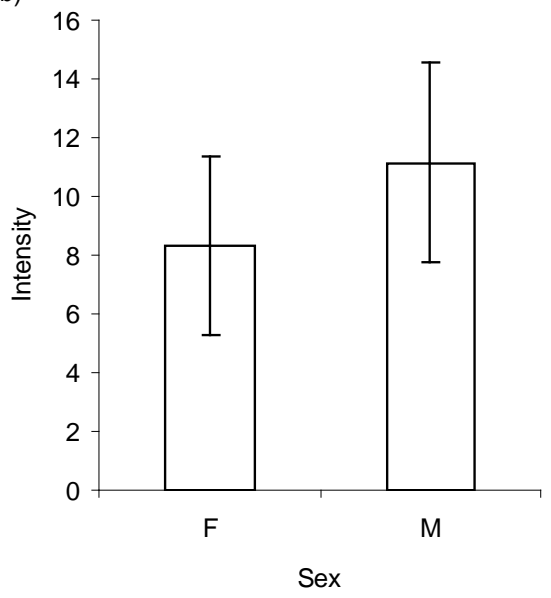

Figure 6. Differences in (a) prevalence and (b) intensity between male and female of $O$. urolepis.

Table 2. Prevalence $(\mathrm{P})$ and intensity (mean $\pm \mathrm{SE}$, with range in parentheses) of parasites of four fish species.

\begin{tabular}{|c|c|c|c|c|c|c|c|c|c|}
\hline \multirow[b]{2}{*}{ Parasite } & \multirow[b]{2}{*}{ Location } & \multicolumn{2}{|c|}{ O. urolepis $(\mathrm{N}=48)$} & \multicolumn{2}{|c|}{ C. congicus $(\mathrm{N}=17)$} & \multicolumn{2}{|c|}{ C. gariepinus $(\mathrm{N}=3)$} & \multicolumn{2}{|c|}{ S. maculipinna $(\mathrm{N}=9)$} \\
\hline & & $\mathrm{P}(\%)$ & Intensity & $\mathrm{P}(\%)$ & Intensity & $\mathrm{P}(\%)$ & Intensity & $\mathrm{P}(\%)$ & Intensity \\
\hline \multicolumn{10}{|l|}{ Crustaecea } \\
\hline Ergasilus sp. & Gills & 20.8 & $2.5 \pm 0.9(1-10)$ & 31.6 & $2.5 \pm 0.9(1-15)$ & 33.3 & $4 \pm 0.0$ & - & - \\
\hline Lamproglena sp. & Gills & 3.2 & $1.0 \pm 0.0(1)$ & - & - & - & - & - & - \\
\hline $\begin{array}{l}\text { Un. Crustacean } \\
\text { Monogenia }\end{array}$ & Gills & - & - & 5.9 & $1.0 \pm 0.0(1)$ & - & - & - & - \\
\hline $\begin{array}{c}\text { Dactylogyrus sp. } \\
\text { Nematodes }\end{array}$ & Gills & 29.2 & $1.9 \pm 0.5(1-8)$ & 5.3 & $1.0 \pm 0.0(1)$ & - & - & - & - \\
\hline Oxyuridae & Intestine & - & - & 73.7 & $37 \pm 11.5(2-527)$ & - & - & 22.2 & $8 \pm 4(4-12)$ \\
\hline $\begin{array}{l}\text { Procamallanus } \\
\text { laevionchus }\end{array}$ & Stomach & - & - & 5.3 & $45(45)$ & - & - & 100 & $10.9 \pm 3.6(2-36)$ \\
\hline Acanthocephala & Intestine & 49.9 & $9.9 \pm 4.7(1-40)$ & - & - & - & - & - & - \\
\hline \multicolumn{10}{|l|}{ Trematodes } \\
\hline Strigeids & Eye & 41.9 & $20.8 \pm 7.6(1-167)$ & - & - & - & - & - & - \\
\hline Diplostomum sp. & Brain & - & - & - & - & 33.3 & $12 \pm 0.0(12)$ & - & - \\
\hline
\end{tabular}




\section{Discussion}

\subsection{Parasite Communities}

The susceptibility of fishes to infestation with parasites differs and depends on various factors, including morphology, immunological characteristics, physiology and diet of the host. The composition of the endo-parasite fauna of a host is dependent upon the host's feeding and other habits as well as host-specificity and distribution of the parasite [12].

In the present study, Cichlidae, Oreochromis urolepis harboured metacercariae, strigeids in the eyes and acanthocephala, in the intestine. Acanthocephala were found only in O. urolepis. [13] found acanthocephala, Acanthocephalus tumescens in the intestine of six out of eight fish species in Lake Moreno Argentina. Crustacean parasites and monogenean were also found in the gills of this species. [14] reviewed parasites, which infect Cichlidae and reported that monogenea, crustacean, trematodes, nematodes and cestodes could infect the group of this family. [15] found trematode, Clinostomum (metacercaria) from four tilapia species in Sudan. From three Clarias gariepinus examined in the present study, Diplostomum sp. was the only trematodes recovered from brain and Ergasilus lamelifer a crustacean from the gills. No parasites were found in the alimentary tract of $C$. gariepinus in this study. This is exciting as many studies have revealed different helminth parasites from the alimentary tract of this species [6] [16] [17]. This could be attributed to the sample size (3) specimens.

Members of Citharinidae were heavily infected with a nematode, Procamalunus laevionchus and members of the family Oxyuridae. In Sudan [15] reported the prevalence of 54\% of Oxyuridae from the alimentary tract of Citharinus citharus. Most Oxyuridae have a direct life cycle where infection of the final host is by ingestion of the eggs. C. congicus in the lower Rufiji floodplain lakes feed on mud with diatoms and coarser plant material and presumably acquire infection with oxyuridae by ingesting the embryonated eggs with its food. In the lower Rufiji floodplain lakes, Labeo congoro did not harbour any parasite but the numbers examined (7) were too small to permit any conclusion. [15] found cestodes, Nematobothrium labeonis in four species of Labeo in Sudan. Nematode, Oxyuridae were also found in the intestine of three Distichodus petersii examined. Synodontis maculipinna were found to harbour nematodes Procamallanus laevionchus and Oxyuridae from stomach and intestine respectively. Probably these species acquired oxyuridae through the same way as Citharirus congicus. Both D. petersii and S. maculipinna are omnivore and benthic feeders.

Crustacean parasites Ergasilus lamelifer was found in several fish species including O. urolepis, Citharinus congicus, Clarias gariepinus and Glossogobius giuris. Monogenean, Dactylogyrus sp. was found in the gills of $O$. urolepis and C. congicus only. Since the number of fish examined were relatively few it is not possible to conclude that these parasites are restricted only to these two species. However, monogeneans have been reported to be one of the most host-specific of parasites and may be the most host-specific of all fish parasites [18].

\subsection{Parasite Communities of Oreochromis urolepis}

[19] found only acanthocephala, Acanthogyrus in the intestine and monogenea, Ciclidogyrus in the gills of different tilapia species from five Ugandan lakes; Victoria, Kyoga, Edward, George and Albert. In the present study, Oreochromis urolepis were found to harbour a high number of trematode and acanthocephala in the eye and intestine respectively. Monogenea, Dactylogyrus sp. was common in the gills. Also crustacean, Ergasilus lamelifer was found in the gills of some fish examined. The high prevalence and intensity of strigeids in the eyes could be attributed to the shallowness of the lakes, which enhance the interaction of the definitive host (birds). Fish living in shallow lakes, with relatively larger littoral zones could be expected to harbour relatively higher proportion of larval parasites than those living in deeper lakes. This is because shallow lakes should offer more opportunities for interactions with birds and are more frequently visited by piscivorous birds [20]. Also during spawning fish tend to aggregate in the littoral where it is easy to come into contact with bird like heron, darter, hammerkorp or kingfisher, which are common in the studied lakes.

\subsection{Prevalence and Intensity in Relation to Host Size}

In the present study, lower size classes and upper classes had few parasites while middle class (160 - $189 \mathrm{~mm})$ had higher prevalence of infection. All fish in higher size classes or older fish had low intensity of infection. Ontogenetic change has been considered as the main factor determining parasite abundance in the alimentary canal due to changes in feeding behaviour as a fish grow. Geets and Olliver 1996 cited in [17] postulated that 
herbivorous fish are generally considered to harbour less intestinal parasites than omnivores or carnivorous. This is because most parasites utilize invertebrates as intermediate host.

Prevalence and intensity of strigeids were higher in the middle size group (160 - 189) and the lowest in the higher size group. This could be attributed to the fact that the higher classes had few specimens and also that fish with higher number of parasites were already removed from the stock before they reach maturity, hence higher size group. For the acanthocephala, size group of $190-219 \mathrm{~mm}$ had the highest prevalence and intensity and the lowest in the lower size group (130 - $159 \mathrm{~mm}$ ). This could be attributed to the changes in diet as fish grow. $O$. uroleis is herbivore, tends to feed on phytoplankton when they are adult, and zooplankton when they are juvenile. Also adult $O$. urolepis feed on other food materials such as detritus, macrophytes and animal materials, which presumably facilitates the transfer of acanthocephala from their intermediate host (crustacean). Furthermore, it has been reported [21] [22] that the larger the fish the more parasite population they generally harbour. However, [23] found that host population size matters or shape the parasite population size rather than host body size or density. In the present study, there was no direct correlation between parasites population and fish size.

\subsection{Prevalence and Intensity in Relation to Sex}

In the present study males had higher prevalence and intensity than females. This can be attributed to the inactive of females since most of them had ripe gonads indicating a spawning period. Spawning fish tend to be inactive hence reducing the chances of contacting the infective stages of the parasite. Changes in the level of hormone, could be considered as a factor reducing the number of parasite in females. [24] found that increase in hormone, ostradiol in frogs was responsible for reducing the number of helminth parasites. Similar findings have been observed by other workers [17] [25] [26]. However, there was no significant difference in parasite abundance between sex, this might be attributed to the feeding ground to be the same. Also tilapia exhibits a parental care therefore during breeding period both males and females aggregate in the same spawning ground or nest.

\subsection{Effect of Parasite on Fish Biology and Fish Production}

Different parasite groups may harm their hosts (fish) in different ways: 1) by causing mechanical injury which could be a point of entry for other pathogens 2) by introducing toxic metabolic by-products and 3) by acting as carriers or vectors of other pathogens [15]. Also, parasite infection alters fish behaviour in many ways; 1) alter foraging behavior 2) locomotion 3) anti-predatory behaviour 4) habitat selection and 5) sexual behaviour [1].

Most digenetic trematodes are not a serious threat to fish health; however, their mere presence often renders the fish undesirable by consumers. The penetration of large numbers of cercariae into a fish can cause death to a fish. A few Diplostomulum in the eye will not kill fish but many will cause blindness and eventual death. Metacercariae of diplostomatid trematodes are common parasites of freshwater fish that frequently migrate to the brain or eyes of their hosts following invasion via the skin. Diplostomum spathaceum metarcecariae, which grows in the lens of the eyes, have been reported to cause parasitic cataract and eyefluke disease [1].

There is evidence that $D$. spathaceum metarcecariae aggregate in areas of the lens receiving minimum illumination, when more extensive, migration through the lens would result in greater damage and more severe effects on vision that may be harmful to parasite as well as the host [27]. Dance infected with $D$. spathaceum were found spending more time at the water surface where they forage on drift items to compensate for their reduced visual acuity [28]. Within the brain metarcecariae aggregate in specific lobes concerned with vision and motor control [29], sites that once damaged are likely to alter escape responses from predators supporting the idea that behavioral alteration by this parasite may be under active predation. Monogeneans and crustaceans thrive best in lentic or near lentic water conditions hence this might affect fish production in this water body. Ergasilus, when present in large numbers, in the gills interfere with respiration [30].

Sometimes fish parasites are associated with a reduction in host reproductive energy/efficiency and they appear to achieve this either through the energetic demand they place on their host or by the release of hormone analogues that block sexual maturation. In Lake Tana, [22] found all infected cyprinids, Barbus tanapelagius and $B$. humilis even larger specimen had immature gonads. If parasitism increases susceptibility of fish to predation, it may also make infected fish more likely to be sampled by humans.

In conclusion, fish parasites cause commercial losses in both the aquaculture and fisheries industries. Also they may have human health, as well as a socio-economic implication. Different parasite species affect fisheries 
by decreasing the yield, spoiling the quality of fish or rendering them aesthetically unacceptable. Henceforth, the control of parasites should be looked upon as a major aspect of the management of ponds, floodplain and lakes fisheries.

\section{Acknowledgements}

Thanks are extended to Fishponds project for financial support and the University of Dar Es Salaam for availing time to conduct this study.

\section{References}

[1] Barber, I., Hoare, D. and Krause, J. (2000) Effects of Parasites on Fish Behaviour: A Review and Evolutionary Perspective. Reviews in Fish Biology and Fisheries, 10, 131-165. http://dx.doi.org/10.1023/A:1016658224470

[2] Palm, H.W. (2011) Fish Parasites as Biological Indicators in a Changing World: Can We Monitor Environmental Impact and Climate Change? In: Mehlhorn, H., Ed., Progress in Parasitology, Parasitology Research Monographs, Springer Verlag, Chapter 12.

[3] Bush, A.O., Fernández, J.C., Esch, G.W. and Seed J.R. (2001) Parasitism: The Diversity and Ecology of Animal Parasites. Cambridge University Press, Cambridge.

[4] Basson, L. and Van As, J.G. (1991) Trichodinids (Ciliophora: Peritrichia) from a Calanoid Copepod and Catfish from South Africa and Notes on Host Specificity. Systematic Parasitology, 18, 147-158. http://dx.doi.org/10.1007/BF00017668

[5] Madanire-Moyo, G. and Barson, M. (2010) Diversity of Metazoan Parasites of the African catfish Clarias gariepinus (Burchell, 1822) as Indicators of Pollution in a Subtropical African River System. Journal of Helminthology, 84, 216-227. http://dx.doi.org/10.1017/S0022149X09990563

[6] Nkwengulila, G. and Mwita, C. (2004) Spatial Distribution of Parasites along the Gut of the Catfish Clarias gariepinus (Burchell, 1822) (Clariidae) from the Mwanza Gulf, Lake Victoria. Tanzania Journal of Science, 30, 64-69.

[7] Moravec, F., Nasincova, V. and Scholz, T. (1991) Methods of Investigating Metazoan Parasites. Endoparasitic Helminthes. Manual for Training Course on Fish Parasites. Institute of Parasitology, Czechoslovak Academy of Sciences, Ceske Budejovice, 22 p.

[8] Yamaguti, S. (1961) Systema Helminthum. Vol. III. The Nematodes of Vertebrates. Part I and II. Interscience Publishers, Inc., New York and London.

[9] Dawes, B. (1968) The Trematoda: With Special Reference to British and Other European Forms. Cambridge University Press, London, $644 \mathrm{p}$.

[10] Margolis, L., Esch, G.W., Holmes, J.C., Kuris, A.M. and Schad, G.A. (1982) The Use of Ecological Terms in Parasitology. Journal of Parasitology, 68, 131-133. http://dx.doi.org/10.2307/3281335

[11] Moran, J.D.W., Arthur, J.R. and Burt, M.D.B. (1996) Parasites of Sharp-Beaked Redfishes (Sebastes fasciatus and Sebastes mentella) Collected from the Gulf of St. Lawrence, Canada. Canadian Journal of Aquatic Sciences, 53, 18211826. http://dx.doi.org/10.1139/f96-115

[12] Chávez, R.A., González, M.T., Oliva, M.E. and Valdivia, I.M. (2012) Endoparasite fauna of Five Gadiformes fish Species from the Coast of Chile: Host Ecology versus Phylogeny. Journal of Helminthology, 86, 10-15.

[13] Raugue, C.A., Viozzi, G.P. and Semenas, L.G. (2003) Component Population Study of Acanthocephalus tumescens (Acanthocephala) in Fishes from Lake Moreno, Argentina. Folia Parasitologica, 50, 72-78. http://dx.doi.org/10.14411/fp.2003.013

[14] Fryer, G. and Iles, T.D. (1972) The Cichlid Fishes of the Great Lakes of Africa. Their Biology and Evolution. Oliver and Boyd, Edinburgh, 641 p.

[15] Khalil, L.F. (1969) Studies on the Helminth Parasites of Freshwater Fishes of the Sudan. Journal of Zoology London, 158, 143-170. http://dx.doi.org/10.1111/j.1469-7998.1969.tb02132.x

[16] Mwita, C. and Nkwengulila, G. (2004) Parasites of Clarias gariepinus (Burchell, 1822) (Pisces: Clariidae) from the Mwanza Gulf, Lake Victoria. Tanzania Journal of Science, 30, 53-61.

[17] Oniye, S.J., Adebote, D.A. and Ayanda, O.I. (2004) Helminth Parasites of Clarias gariepinus (Teugels) in Zaria, Nigeria. Journal of Aquatic Sciences, 19, 71-75. http://dx.doi.org/10.4314/jas.v19i2.20027

[18] Whittington, I.D., Cribb, B.W., Hamwood, T.E. and Halliday, J.A. (2000) Host-Specificity of Monogenean (Platyhelminth) Parasites: A Role for Anterior Adhesive Areas? International Journal for Parasitology, 30, 305-320. http://dx.doi.org/10.1016/S0020-7519(00)00006-0

[19] Khalil, L.F. and Thurston, J.P. (1973) Studies on the Helminth Parasites of Freshwater Fishes of Uganda Including the 
Descriptions of Two New Species of Digenians. Revue de Zoologie et de Botanique Africaine, 87, 209-247.

[20] Bell, G. and Burt, A. (1991) The Comparative Biology of Parasite Species Diversity: Internal Helminths of Freshwater Fish. Journal of Animal Ecology, 60, 1047-1063. http://dx.doi.org/10.2307/5430

[21] Bagge, A.M. and Valtonen, E.T. (1999) Development of Monogenean Communities on the Gills of Roach Fry (Rutilus rutilus). Parasitology, 118, 479-487. http://dx.doi.org/10.1017/S0031182099004011

[22] Dejen, E.D. (2003) Ecology and Potential for Fishery of the Small Barbs (Cyprinidae, Teleostei) of Lake Tana, Ethiopia. Ph.D. Thesis, Wageningen University, Wageningen, $180 \mathrm{p}$.

[23] Bagge, A.M., Poulin, R. and Valtonen, E.T. (2004) Fish Population Size, and Not Density, as the Determining Factor of Parasite Infection: A Case Study. Parasitology, 128, 305-313. http://dx.doi.org/10.1017/S0031182003004566

[24] Lees, E. and Bass, L. (1960) Sex Hormone as a Possible Factor Influencing the Level of Parasitisation in Frog. Nature, 188, 1207-1208. http://dx.doi.org/10.1038/1881207a0

[25] Müller, G. (1995) Prevalence and Abundance of Two Trematode Parasites, Diplostomum phoxini and Macrolecithus papilliger in European Minnows (Phoxinus phoxinus) in an Artificial Swiss Alpine Lake. Aquatic Sciences, 57, 119-126. http://dx.doi.org/10.1007/BF00877380

[26] Mwita, C.J. (2002) Diversity and Abundance of the Parasite Fauna of the Catfish Clarias gariepinus (Burchell, 1822) (Clariidae) from the Mwanza Gulf, Lake Victoria. M.Sc. Thesis, University of Dar es Salaam, Dar es Salaam, 157 p.

[27] Gaten, E. (1987) Aggregation of the Eyefluke Diplostomum spathaceum (Digenea: Diplostomatidae) in the Lenses of Various Species of Fish. Journal of Fish Diseases, 10, 69-74. http://dx.doi.org/10.1111/j.1365-2761.1987.tb00721.x

[28] Crowden, A.E. (1976) Diplostomum spathaceum in the Thames; Occurrence and Effects on Fish Behaviour. Parasitology, 73, vii.

[29] Barber, I. and Crompton, D.W.T. (1997) The Distribution of Diplostomum phoxini Metarcecariae (Trematoda) in the Brain of Minnows (Phoxinus phoxinus). Folia Parasitology, 44, 19-25.

[30] Vinobaba, P. (2007) Histopathological Changes Induced by Ergasilid Copepod Infections on the Gills of Food Fish from Batticaloa Lagoon, Sri Lanka. Sri Lanka Journal of Aquatic Science, 12, 77-87. 
Scientific Research Publishing (SCIRP) is one of the largest Open Access journal publishers. It is currently publishing more than 200 open access, online, peer-reviewed journals covering a wide range of academic disciplines. SCIRP serves the worldwide academic communities and contributes to the progress and application of science with its publication.

Other selected journals from SCIRP are listed as below. Submit your manuscript to us via either submit@scirp.org or Online Submission Portal.
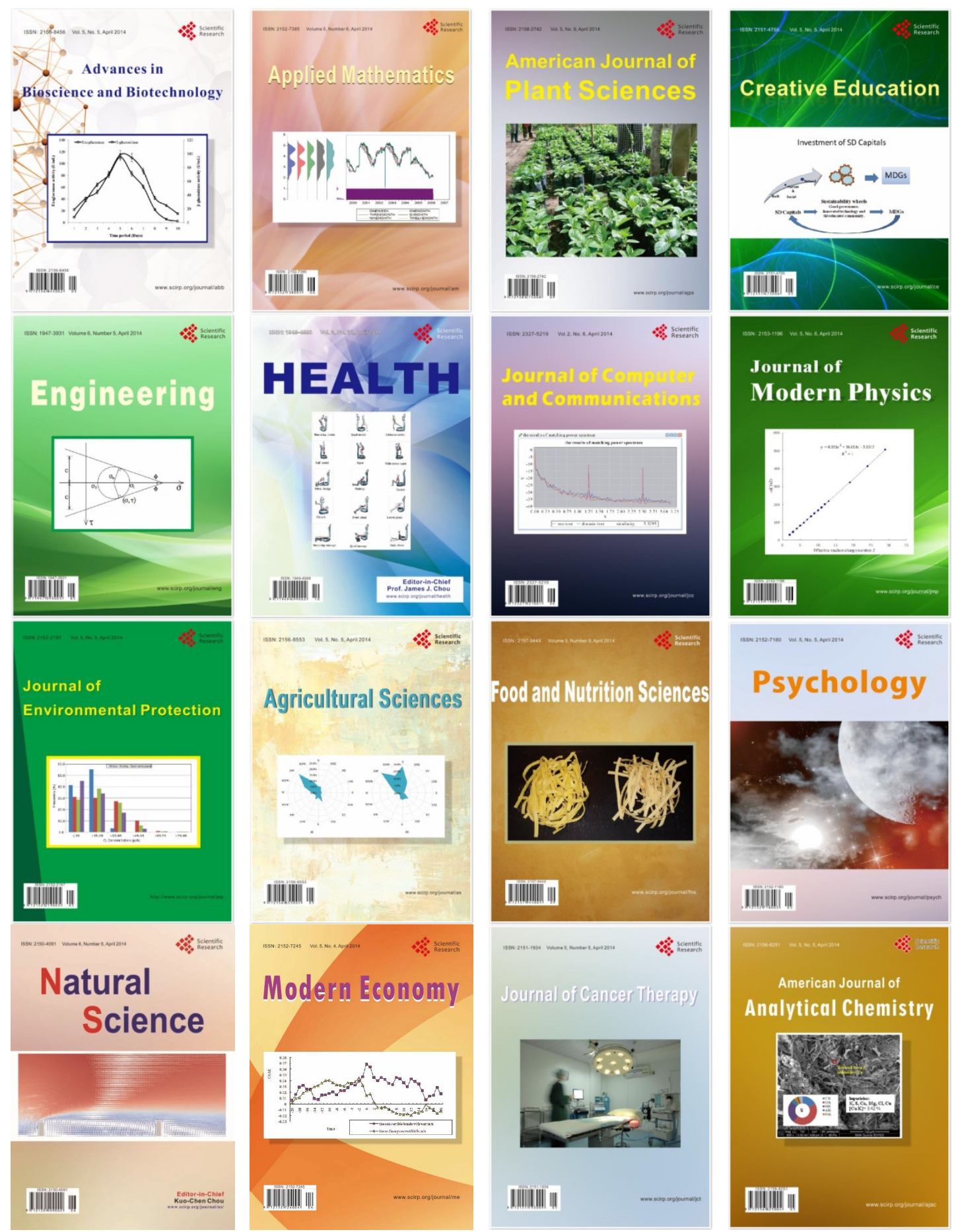